\title{
Presence of Anti-Toxocara Antibodies in Sheep from the State of Mexico
}

\author{
Camilo Romero ${ }^{1}$, Rafael Heredia ${ }^{2}$, Saira Aguilar ${ }^{1}$, Nadyeli Nava² ${ }^{2}$ Jocelyn Pineda $^{1}$ \\ Universidad Autónoma Del Estado de México, ${ }^{1}$ Centro Universitario UAEM Amecameca, Amecameca, \\ ${ }^{2}$ Doctorado en Ciencias Agropecuarias y Recursos Naturales, Toluca, México \\ Received September 8, 2015 \\ Accepted August 31, 2016
}

\begin{abstract}
Toxocariasis is a parasitic zoonosis caused by the nematode Toxocara canis, and less frequently Toxocara cati, whose final hosts are the dog and cat, respectively. It is acquired by the ingestion of embryonated parasite eggs; the ingestion of meat from animals carrying cystic larvae plays a central role in this disease. The study was conducted in Ayapango, Mexico. Ninety-two sheep where used, of which 72 were females and 20 males. The total prevalence of anti-Toxocara antibodies was $15.21 \%$ (14/92), ranging from $17.24 \%$ in the one to six months age group to $14.28 \%$ in the group older sheep six months, with a higher percentage in females $(19.44 \%)$ compared to males $(5.0 \%)$, with a significant difference between positive males and females older than six months of age (Chi-square test $=4.22, P<0.05$ ). The prevalence of antiToxocara antibodies in sheep suggests that a high number of animals are infected with Toxocara spp. The consumption of meat from paratenic hosts, including sheep, is considered a means of transmission of toxocariasis to humans.
\end{abstract}

\section{Seroprevalence, larva migrans, zoonoses, ELISA}

Toxocariasis is one of the most commonly reported helminth zoonotic infections throughout the world. Its main aetiological agent is the Toxocara canis nematode, and less frequently Toxocara cati, whose final hosts are the dog and cat, respectively (Rubinsky 2004; Radman et al. 2006; Marino et al. 2011). It is acquired through the ingestion of embryonated eggs exposed to infected soil, geophagy, poorly washed hands, onychophagy, as well as the ingestion of vegetables with animal faeces and larvae encysted in the tissue of paratenic hosts (various animals) (Del Valle et al. 2002; Strube et al. 2013; Ferrero et al. 2014). These animals host hypobiotic larvae in the liver and other tissues, which can be transmitted to humans through the ingestion of raw or undercooked meat (De La Fé et al. 2006; Lescano et al. 2012). However, there is little information available on the prevalence of $T$. canis infection in humans trough paratenic hosts such as horses, sheep, birds, etc. (Alvarez et al. 2011). The objective of the present study was to determine the presence of Toxocara antibodies in sheep of Ayapango, Mexico State, Mexico.

\section{Materials and Methods}

This study was conducted from September to November 2013 in the municipality of Ayapango, Mexico $\left(19^{\circ} 10^{\prime} \mathrm{N}, 98^{\circ} 45^{\prime} \mathrm{W}\right.$ and 2,450 metres above sea level). Ninety-two sheep were used, within the age range from one to 24 months, of which 72 were females and 20 were males. Jugular venipuncture blood samples were taken to measure the level of anti-Toxocara antibodies. The selection of all of the animals included in this study followed random allocation criteria.

The anti-Toxocara IgG antibody levels were evaluated using a commercial kit SCIMEDX Toxocara Microwell Serum ELISA indirect format, using antigen excretion/secretion of Toxocara larvae 2, with a dilution of 1:64 test samples, and using protein "A" conjugated to peroxidase. Reading of optical densities was conducted with a spectrophotometer (Victor WallacK 120) (Heredia et al. 2014), using a 0.3 cut-off point diopter for the positives. All the data obtained were registered to compare the prevalence between sexes and ages, using a test of Chi-square and ODDS ratio to measure the relative risk for the same variables, using a $95 \%$ confidence interval and significance of $P<0.05$.

Address for correspondence:

Camilo Romero Núñez, Ph.D

Centro Universitario UAEM Amecameca

Universidad Autónoma Del Estado de México

Carrtera Amecameca-Ayapango km. 2.5

56900, Amecamenca de Juárez, Estado de México

Phone: +15979 782158

E-mail: cromeron@uaemex.mx

http://actavet.vfu.cz/ 
Ethical statement

The research protocol was approved by the Ethics Committee of the Autonomous University of the State of Mexico.

\section{Results}

The total prevalence of anti-Toxocara antibodies was $15.21 \%$ (14/92), ranging from $17.24 \%$ in the age group of one to six months to $14.28 \%$ in the group of sheep older than six months, with a higher percentage in females $(19.44 \%)$ compared to males $(5.0 \%)$. The frequency of antibodies was directly proportional to the age of the animals, with no significant differences between sexes in animals aged from one to six months. A difference was found in males (Chi-square $=4.58, P<0.03$ ) older than six months, yet none of the variables (age and sex) were shown to be a risk factor for the presence of antibodies against Toxocara (Table 1). A significant difference was found (Chi-square $=4.22$, $P<0.03)$ comparing the differences between positives from different sexes in sheep over six months of age (Table 2).

Table 1. Seroprevalence of Toxocara canis association and risk factor between ages and sexes of sheep from Ayapango, Mexico, from September to November 2013.

\begin{tabular}{|c|c|c|c|c|c|c|c|}
\hline & $\begin{array}{c}\text { Positive } \\
n=14\end{array}$ & $\begin{array}{c}\text { Negative } \\
\mathrm{n}=78\end{array}$ & Chi-square & $P$-value & OR & $P$-value & CI $(95 \%)$ \\
\hline \multicolumn{8}{|c|}{0 to 6 months } \\
\hline Males & $1(7.1 \%)$ & $4(5.1 \%)$ & 0.08 & 0.7 & 1.42 & 0.76 & $0.14-13.6$ \\
\hline Females & $4(28.5 \%)$ & $20(25.6 \%)$ & 0.03 & 0.86 & 1.16 & 0.81 & $0.32-4.11$ \\
\hline \multicolumn{8}{|c|}{ Over 6 months } \\
\hline Males & $0(0.0 \%)$ & $15(19.2 \%)$ & 4.58 & 0.03 & 0.48 & 0.63 & $0.02-9.5$ \\
\hline Females & $9(64.2 \%)$ & $39(50.0 \%)$ & 0.28 & 0.59 & 1.8 & 0.32 & $0.55-5.85$ \\
\hline
\end{tabular}

OR - ODDS ratio, CI - confidence interval, $P \leq 0.05$

Table 2. Comparison between ages and sexes positive for Toxocara canis antibody in sheep from Ayapango, Mexico of September to November 2013.

\begin{tabular}{lcccc}
\hline Positive & Males (20) & Females (72) & Chi-square & $P$-value \\
\hline Total & 1 & 13 & 1.63 & 0.20 \\
Under 6 months of age & 1 & 4 & 0.008 & 1 \\
Over 6 months of age & 0 & 9 & 4.22 & 0.03 \\
\hline
\end{tabular}

$P \leq 0.05$

\section{Discussion}

Literature data on the prevalence of Toxocara spp. in paratenic guests are limited; however, some studies of sheep report higher prevalence rates than those found in this study, such as the study by Lloyd et al. (2006) carried out in the country of Wales. Four hundred serum samples were evaluated with ELISA test reporting a $T$. canis antibody positivity of $13 \%$ in six-month-old sheep, which is still less than the $17.24 \%$ found in the present report. Ten-month-old sheep were reported to have a $16 \%$ positivity rate in the sample; and $31 \%$ positivity rate was found in 15 -month-old sheep. Both values exceed 
those found in our study of sheep older than six months (14.28\%). In both studies an increase of positive samples in older animals was noted, which could be related to greater animal contact with infective forms of $T$. canis.

Kantzoura et al. (2013) found in a study conducted in Thessaly, Greece 42.9\% seroprevalence of Toxocara canis in sheep (361/155), triple than that found by us. The authors attribute the prevalence to temperature and rainfall which facilitate incubation and subsequent dissemination of Toxocara eggs. Another mentioned risk drivers are the conditions such as the sheep's feed; seroprevalence increases when animals graze and decreases when they are stabled.

A study carried out in Brazil on anti-T. canis antibodies in sheep reported that the overall prevalence of antibodies was $50.1 \%$ (183/365), which exceeds the number reported in this study, where it was found in $15.21 \%$ of the tested sheep in Ayapango, Mexico. The same study reported $6.01 \%$ of positive samples in the group aged one to six months and $61.2 \%$ in the group aged between 10 and 15 months, which is contrary to the results presented in this study where the sheep under six months of age had higher positive samples $(17.24 \%)$ compared with samples from sheep over six months of age (14.28\%) (Alvarez et al. 2011).

Another study in the south of Brazil, with 1,642 sheep serum samples, reported that the frequency of anti-Toxocara antibodies was $29.0 \%$ (477/1642), which is still higher than what was found in this investigation. These results indicate that infection by T. canis is widely distributed among sheep, representing a potential risk for human health (Muñoz et al. 2010; Overgaauw et al. 2013; Rassier et al. 2013).

The prevalence of anti-Toxocara antibodies in sheep suggests that a high number of animals are infected with Toxocara spp.; these animals can host hypobiotic larvae in the liver and other tissues that could be transmitted to humans by ingestion of raw or undercooked meat. In addition, transmission of larvae from meat to wild and domestic animals could perpetuate the parasites' life cycle in their definitive hosts (Radman et al. 2006; Alvarez et al. 2011).

Consumption of meat from paratenic hosts, including sheep, is considered a transmission route of toxocariasis to humans (Salem and Schantz 1992). Plenty of studies have considered the consumption of raw or undercooked meat as a risk factor because of the Toxocara larvae (Alvarez et al. 2011).

The overall prevalence of anti-Toxocara antibodies (15.2\%) in sheep in Ayapango, Mexico, is lesser than that reported in studies from other parts of the world. However, these results highlight a little-studied problem, which could participate in the perpetuation of toxocariasis in their final and paratenic hosts, including humans. Thus, monitoring the animals' health status and providing guarantees regarding appropriate production and animal conditions is important.

\section{Conflict of Interests}

The authors declare they have no conflict of interest.

\section{References}

Alvarez V, Fabris PA, Leme BE, Rubinsky-Elephant G, Guiffrida R 2011: Anti-Toxocara spp. antibodies in sheep from southeastern Brazil. Vet Parasitol 179: 283-286

Del Valle GM, Radman NE, Burgos L, Fonrouge R, Archelli SM 2002: Toxocara canis: Migración larval y eosinofílica en el hospedador paraténico. Parasitol latinoam 57: 46-49

De La Fé P, Duménigo RB, Brito AE, Aguiar SJ 2006: Toxocara canis y síndrome larva migrans visceral. Rev Electron Vet 7: 1-42

Ferrero M, Sánchez RJ, Pizzi RD, Pizzi HL 2014: Determinación de anticuerpos IgG anti-Toxocara canis en estudiantes de medicina. Rev Salud Publica 18: 36-43

Heredia R, Romero C, Mendoza GE, Ponce M, Portal A, González L, Bautista LG 2014: Occurrence of Toxocara canis in students of veterinary and graphic design in a Mexican University. Acta Sci Vet 42: 1-6 
Kantzoura V, Diakou A, Kouamc MK, Feidas H 2013: Seroprevalence and risk factors associated with zoonotic parasitic infections in small ruminants in the Greek temperate environment. Parasitol Int 62: 554-560

Lescano SA, Nakhle MC, Ribeiro MC, Chieffi PP 2012: IgG antibody responses in mice coinfected with Toxocara canis and other helminths or protozoan parasites. Rev Ins Med Trop São Paulo 54: 145-152

Lloyd S 2006: Seroprevalence of Toxocara canis in sheep in Wales. Vet Parasitol 137: 269-272

Marino GL, Bojanich MV, López MD, Alonso JM 2011: Prueba de avidez de los anticuerpos de IgG en la infección por Toxocara canis. Acta Bioquim Clin L 145: 323-327

Muñoz MA, Alba HF 2010: Secretory-excretory antigens of Toxocara canis recognized by puppies of the Mexico City metropolitan area. Vet Mex 41: 59-64

Overgaauw PA, Van Knapen F 2013: Veterinary and public health aspects of Toxocara spp. Vet Parasitol 193: 398-403

Radman NE, Archelli MS, Burgos L, Fonrouge RD, Del Valle M 2006: Toxocara canis en caninos, prevalencia en la ciudad de La Plata. Acta Bioquim Clin L 40: 41-48

Rassier GL, Pappen FG, Borsuk S, Scaini CJ, Gallina T, Pinto JS, Rodrigues S, Berne ME 2013: Toxocara spp. seroprevalence in sheep from Southern Brazil. Parasitol Res 112: 181-187

Rubinsky-Elephant G 2004: Human toxocariasis: Humoral response (IgG, IgA and IgE) anti-Toxocara canis and clinical-laboratorial correlation in patients following chemotherapy. Rev Ins Med Trop São Paulo 46: 76-81

Salem G, Schantz P. 1992: Toxocara visceral larva Migrans after ingestion of raw lamb liver. Clin Infec Dis 15: 743-744

Strube C, Heuer L, Janecek E 2013: Toxocara spp. infections in paratenic hosts. Vet Parasitol 193: 375-389 